\title{
KONSTRUKSI BUDAYA MASKULIN DALAM IKLAN
}

\author{
Agus Ganjar Runtiko \\ Staf Dosen FISIP Universitas Jenderal Soedirman Purwokerto \\ Jl. Prof.Dr. Boenyamin No 993 Purwokerto Jawa Tengah 53122 \\ (Naskah diterima 14 Maret 2011 - Revisi 15 April 2011)
}

\begin{abstract}
Abstrak
Tujuan dari makalah ini adalah untuk mempelajari: (1) membangun maskulinitas dalam iklan televisi rokok 'Djarum Super', (2) mitos maskulinitas yang diwakili dalam iklan televisi rokok 'Djarum Super', (3) iklan televisi tema rokok 'Djarum Super' yang mewakili mitos maskulinitas. Pendekatan yang digunakan dalam penelitian ini adalah pendekatan kualitatif dengan metode semiotika Barthes. Dengan menggunakan metode semiotika Barthes, isi pesan iklan dan bagaimana bentuk pesan dapat dianalisis dengan menggunakan kombinasi dari penanda dan petanda. Selama penelitian ini, tanda-tanda kemudian diinterpretasikan ke alamat tujuan penelitian.

Objek penelitian ini adalah tiga versi iklan televisi rokok 'Djarum Super' komersial, yaitu versi 'Petualangan Olahraga', versi 'Soccer', dan versi 'Bulutangkis', yang diiklankan selama bulan Juni 2009. Data dikumpulkan dengan menangkap iklan dari televisi. Tanda-tanda dalam iklan, baik verbal dan visual, dipisahkan sebelum diuraikan berdasarkan struktur penanda dan petanda. Setelah tanda tersebut digambarkan, berarti iklan diidentifikasi dalam hal bagian konotatif dan denotatif.

Ada beberapa kesimpulan dari hasil analisis penelitian. Kesimpulan pertama menunjukkan bahwa maskulinitas cenderung untuk membangun sebagai laki-laki yang selalu mewah untuk hidup bebas, bertualang, keberanian, memiliki hubungan sosial yang luas, dan melindungi perempuan. Kedua, mitos yang muncul: orang-orang bebas, kuat, berani, dll kesimpulan paling akhir bahwa olahraga adalah tema utama yang ditampilkan oleh iklan-iklan televisi rokok 'Djarum Super'.
\end{abstract}

Kata kunci: Budaya Maskulin, Rokok Iklan, Semiotika

\begin{abstract}
The objectives of this thesis are to learn: (1) masculinity construct in 'Djarum Super' cigarette television commercial, (2) myth of masculinity that represented in 'Djarum Super' cigarette television commercial, (3) theme of 'Djarum Super' cigarette television commercial that represent myth of masculinity.

The approach used in this research is qualitative inquiry in nature with semiotics method of Barthes. By using Barthes semiotics method, the contents of advertising messages and how to form messages can be analysed using the combination of signifier and signified. During the research, the signs were then interpreted to address the objectives of the research.

The research objects were three version of 'Djarum Super' cigarette television commercial, namely 'Adventure Sports' version, 'Soccer' version, and 'Badminton' version, which were advertised during June 2009. The data were collected by capturing the commercials from television. The signs in commercials, both verbal and visual, were separated before being elaborated based on structures of signifier and signified. After those signs were described, advertisement meaning was identified in terms of connotative and denotative parts.

There are some conclusions from result of research analysis. The first conclusion has shown that masculinity tend to construct as men that always fancy to free life, adventuring, bravery, have wide social relationship, and protecting woman. Secondly, myths that emerge: the men are free,
\end{abstract}


strong, brave, etc. The lattest notes that sports is main theme that displayed by 'Djarum Super' cigarette television commercials.

Keywords : Masculine culture, Cigarette Advertising, Semiotics

\section{PENDAHULUAN}

Sistem nilai, norma, stereotype, serta ideologi gender telah lama dilihat sebagai salah satu faktor yang memengaruhi posisi serta hubungan antara laki-laki dan perempuan, ataupun dengan lingkungannya dalam konstruksi sosial masyarakat. Nilai atau norma tentang laki-laki dalam masyarakat tumbuh dari konsensus dalam masyarakat itu sendiri yang dibawa secara turun-temurun, meskipun seiring perkembangan jaman, tata nilai tersebut akan terus berkembang dengan mengalami dekonstruksi, redefinisi, maupun rekonstruksi dalam proses sosialnya. Meskipun demikian, cara pandang tentang laki-laki ataupun ideologi gender tidak dapat dilepaskan dengan nilai kultural yang melingkupi hubungan sosial masyarakatnya. Hal ini disebabkan adanya prakonsepsi yang telah diterima sebagai konsensus bersama, legitimasi moral dari kelompok yang dominan, serta internalisasi ideologi yang dijadikan dasar interaksi maupun pandangan dalam hubungan sosial, baik itu untuk menjaga stabilitas, maupun penghindaran konflik. Dengan demikian, cara pandang hubungan gender sebaiknya dikaitkan dengan konteks kultural, historis, dan semangat jamannya.

Adapun fenomena gender yang menjadi diskursus sosial cenderung masih meredefi nisi peran-peran sosial dalam mencari ke adilan gender. Diskursus gender inipun kadang tidak berjalan secara linier. Hal ini sangat dipengaruhi oleh dinamika ekonomi, politik, serta hegemoni ideologi dari kelompok dominan dalam struktur masyarakat. Meskipun terdapat perubahan pandangan dalam melihat realitas hubungan gender, fenomena yang tampak belum banyak berbicara tentang kualitas daripada kuantitas. Re alitas sosial yang demikian ini paling tidak telah menunjukkan adanya hegemoni ideologi patriarki yang kuat dalam pranata sosial.

Perkembangan industri media seringkali dikaitkan dengan perkembangan masyarakat informasi. Dalam konteks masyarakat seperti ini, media memiliki peran yang signifikan. Media merupakan sarana komunikasi antarsubjek, dan merupakan medium yang menjembatani relasi komunikasi seluruh anggota masyarakat. Sehingga dengan demikian media merupakan instrumen komunikasi yang sangat vital dalam masyarakat.

Keluarga, teman, guru dan pemimpin masyarakat, semuanya memainkan peranan dalam membentuk konstruksi mengenai lakilaki. Industri media juga memainkan peranan pembentukan konstruksi laki-laki yang tidak kalah kuat dalam masyarakat. Dalam kebanyakan media, karakter pria selalu dikaitkan dengan kemandirian, agresi dan kekerasan, kebebasan finansial, dan menarik secara fisik.

Konstruksi sosial laki-laki dalam media secara mencolok setidak-tidaknya dapat kita jumpai dalam iklan. Beberapa, kalau tidak dikatakan semua, iklan memanfaatkan kodekode sosial dengan mengambil perspektif gender. Produk-produk yang diiklankan tidak hanya menawarkan fungsi dan kelebihan produk, namun telah memberikan muatan nilai-nilai sosial berbasis gender yang diterima masyarakat.

Sebagai sebuah elemen dalam media massa, periklanan mempunyai potensi menjadi parameter atau implementasi wacana gender yang menggugat adanya bias-bias ketidakadilan gender. Bahkan, dengan agak sinis periklanan dikatakan sebagai sarana legitimasi hegemoni ideologi, sekaligus pelestari dominasi ideologi patriarkis.

Sebuah produk deterjen misalnya, seringkali akan divisualisasikan dengan keadaan rumah tangga. Biasanya, semua orang dalam rumah tangga tersebut melakukan kegiatan-kegiatan publik, sang anak pergi ke sekolah, sedangkan suami pergi ke kantor. Lain halnya dengan sang ibu yang selalu berada di rumah, selanjutnya bertindak sebagai penanggung jawab keadaan rumah. Tanggung jawab lain yang harus dibereskan oleh sang ibu adalah mencuci pakaian seluruh anggota keluarga. Seringkali noda pakaian 
suami dan anak-anak berasal dari kegiatan publik mereka, lumpur ketika anak-anak bermain, atau noda terkena tinta ketika suami di kantor, adapun noda pakaian yang menempel pada pakaian sang ibu berasal dari kegiatan domestiknya, karena kegiatan memasak misalnya.

Sekilas lalu, visualisasi seperti ini terlihat lumrah sebagaimana sering kita lihat dalam kehidupan sehari-hari. Perempuan sebagai ibu rumah tangga berperan sebagai subjek gender yang bertanggung jawab terhadap keadaan rumah tangga, dalam hal ini kebersihan pakaian seluruh anggota keluarga. Visualisasi dalam iklan tersebut biasanya menggambarkan ibu rumah tangga yang tidak bekerja. Tetapi, bahkan dalam rumah tangga dimana seorang ibu bekerja, mereka tetap menjadi subjek gender yang bertanggung jawab terhadap keadaan rumah tangga. Sementara itu, konstruksi mengenai laki-laki akan berbeda halnya. Laki-laki, dalam kasus iklan deterjen di atas misalnya, dikonstruksi sebagai ayah yang bekerja. Karena pekerjaannya, baju yang dipakai sang ayah kemudian kotor, akhirnya sang ibu yang menganggur di rumah bertugas membersihkannya. Visualisasi iklan yang bermuatan bias gender lainnya dapat dilihat juga pada iklan-iklan produk untuk anak-anak. Misalnya saja produk susu formula untuk anak-anak. Sekali lagi, biasanya sang ibu divisualisasikan sebagai sosok yang bertanggung jawab dalam mengatur urusan rumah tangga, terutama tanggung jawab terhadap tumbuh kembang anak. Ibu seakan-akan se orang diri berkewajiban menjaga sang anak, menjaga anak dari sakit, mengatur asupan yang dikonsumsi sang anak, hingga menemaninya bermain. Visualisasi selanjutnya dapat ditebak, susu formula tersebut divisua lisasikan dapat membantu tanggung jawab sang ibu dalam memelihara sang anak, membantu tumbuh kembang anak, dan seterusnya.

Pertentangan pemosisian peranan $\mathrm{pu}$ blik dan peranan privat telah jamak direpre sentasikan oleh iklan. Kebanyakan analisis gender dan media (massa) berfokus pada pe rempuan dan/atau femininitas. Kajian-kajian mutakhir tentang media membuktikannya (Pungente, dalam Budiman, 2000:82). Hal ini agaknya tidak dapat dilepaskan dari persepsi umum bahwa perempuan merupakan makhluk yang lebih "bermasalah" daripada laki-laki. Selain itu, perempuan juga lebih banyak digambarkan sebagai makhluk biologis semata. Penggambaran seperti ini se ringkali dijumpai dalam iklan-iklan produk yang dikhususkan untuk pria, misalnya produk toiletris pria.

Kajian femininitas yang cenderung lebih berat dibandingkan kajian maskulinitas, membuat keadaan menjadi bersifat paradoksal, terutama pada kecenderungan kajian fe mininitas menelantarkan beberapa aspek kekuasaan laki-laki. Apabila dicermati secara lebih mendalam, pengkajian mitos-mitos maskulinitas secara tidak langsung akan membawa keseimbangan kajian gender, bahwa ketidakadilan gender ini akan menimpa siapa saja, dan bukan hanya pihak perempuan saja yang merugi akibat konstruksi budaya patriarki ini.

Iklan yang membawa mitos maskulinitas dapat dengan mudah kita jumpai dalam produk-produk tertentu. Misalnya saja produk pembersih muka, parfum, pisau cukur, minuman energi atau rokok. Produk-produk tersebut dikonstruksi seakan-akan hanya untuk laki-laki saja. Pembersih muka atau parfum misalnya, diidentifikasikan dengan harum yang jantan atau macho. Pisau cukur juga identik dengan kebersihan yang macho. Demikian juga halnya dengan minuman dan rokok. Iklan-iklan tersebut seakan-akan hendak menampilkan bahwa sosok laki-laki ideal sebenarnya haruslah mempunyai badan yang atletis, bersih, harum dan bekerja dalam ranah publik. Namun demikian, produkproduk yang dikonstruksikan untuk perempuan biasanya juga membawa serta ideologi maskulinitas didalamnya, walaupun ideologi tersebut dimuat secara implisit dan berlipat.

Berdasarkan uraian tersebut, maka masalah penelitian yang akan diangkat adalah Bagaimana konstruksi maskulinitas dalam iklan televisi rokok 'Djarum Super'? Mitos maskulinitas apa saja yang direpresentasikan dalam iklan televisi rokok 'Djarum Super'? Bagaimana tema iklan televisi 'Djarum Super' merepresentasikan mitos maskulinitas? 


\section{METODE PENELITIAN}

Metode penelitian ini adalah interpretif, oleh karena itu analisisnya bersifat kualitatif. Menurut Geertz (dalam Muhadjir, 2000:19), metode penelitian interpretif berusaha mencari makna, dan bukan hukum, berupaya memahami, dan bukan mencari teori. Budaya, menurut Geertz, tidak ada social facts yang menunggu observasi kita, melainkan yang ada adalah kesiapan peneliti untuk memberi makna atas observasinya.

Analisis semiotika dipilih peneliti untuk menganalisis teks yang diambil. Sebenarnya terdapat setidak-tidaknya tiga model analisis teks kualitatif, yakni analisis framing, analisis wacana, dan analisis semiotika. Peneliti memilih analisis semiotika karena menyesuaikan dengan maksud dan tujuan penelitian, yakni untuk mengetahui konstruksi maskulinitas, representasi pria dan tema umum yang dimunculkan dalam rokok.

Penelitian ini menitikberatkan pada fenomena keseharian yang mengandung konotasi dan mitologi dalam semiotika yang dikembangkan oleh Roland Barthes. Barthes, sebagaimana Saussure, tidak meninggalkan tanda yang dibagi menjadi penanda-petanda. Barthes justru lebih memperjelas kedudukan tanda dan bagaimana tanda bekerja seperti pada tabel 1 .

Peta ini akan mempermudah peneliti dalam memahami bagaimana tanda bekerja, terutama dalam visualisasi iklan rokok. Penanda dan petanda yang ada dalam penelitian ini difokuskan pada bentuk-bentuk visual.

Selain itu, peneliti mencoba untuk menganalisis tanda-tanda dalam iklan televisi
Djarum Super tersebut dengan Teori Kode Roland Barthes. Teori ini akan memudahkan pembaca menilai tingkatan konotasi sebuah teks. Barthes di dalam bukunya mengembangkan teori kode dengan cara mendekonstruksi atau membongkar teks Balzac Sarrasine, yaitu dengan memecahnya menjadi beberapa bagian untuk dikaji, memberinya nomor dan kemudian merekonstruksinya kembali menjadi 48 tema. Dari ke-48 tema tersebut, Barthes menghasilkan konstruksi lima macam kode yang berbeda, atau yang disebutnya secara lebih populer kode yang lima (Piliang, 2003: 169). Pertama, kode hermeneutik. Di bawah kode hermeneutik, orang akan mendaftar beragam istilah (formal) yang berupa sebuah teka-teki (enigma) dapat dibedakan, diduga, diformulasikan, dipertahankan, dan akhirnya disingkapi. Atau dengan kata lain, kode hermeneutik berhubungan dengan teka-teki yang timbul dalam sebuah wacana. Siapakah mereka? Apa yang terjadi? Halangan apakah yang muncul? Bagaimanakah tujuannya? Jawaban yang satu menunda yang lain. Kode ini disebut pula sebagai suara kebenaran (The Voice of Truth).

Kedua, kode proairetik atau kode narasi. Merupakan tindakan naratif dasar (basic narative action), yang tindakantindakannya dapat terjadi dalam berbagai sikuen yang mungkin diindikasikan. Kode ini disebut pula sebagai suara empirik.

Ketiga, kode budaya. Sebagai referensi kepada sebuah ilmu atau lembaga ilmu pengetahuan. Biasanya orang mengindikasikan kepada tipe pengetahuan (fisika, fisiologi, sejarah, dan sebagainya).

Tabel 1

Peta Bekerjanya Tanda

\begin{tabular}{|c|c|}
\hline 1. PETANDA & 2. PENANDA \\
\cline { 1 - 1 } 3. TANDA DENOTATIF & \\
\hline 4. PENANDA KONOTATIF & 5. PETANDA KONOTATIF \\
\hline \multicolumn{2}{|c|}{ 6. TANDA KONOTATIF } \\
\hline
\end{tabular}

Sumber: Barthes (dalam Cobley dan Jansz, 2002:51) 
Kemudian, dicoba untuk mengonstruksikan sebuah budaya yang berlangsung pada satu kurun waktu tertentu yang berusaha untuk diekspresikan. Kode ini disebut pula sebagai suara ilmu.

Keempat, kode semantik. Kode ini merupakan sebuah kode relasi penghubung (medium-relatic-code), yang merupakan konotasi dari orang, tempat, obyek, yang petandanya adalah sebuah karakter (sifat, atribut, predikat). Misalnya konotasi femininitas, maskulinitas. Atau dengan kata lain, kode semantik adalah tanda-tanda yang ditata sehingga memberikan suatu konotasi maskulin, feminin, kebangsaan, kesukuan, loyalitas.

Kelima, kode simbolik. Tema merupakan sesuatu yang tidak stabil, dan tema ini dapat ditentukan dan beragam bentuknya sesuai dengan pendekatan sudut pandang (perspektif) yang digunakan. Kode simbolik juga berkaitan dengan psikoanalisis, antitesis, kemenduaan, pertentangan dua unsur, skizofrenia.

Bagi Barthes, proses berkarya adalah proses silang-menyilangnya lima kode di atas, yang menciptakan semacam jaringan kodekode yang disebut toposi. Sebuah teks yang dibentuk oleh topos, meskipun demikian, bukanlah teks yang monolitik, stabil, dan otonom-yang memiliki makna ideologis yang mapan-akan tetapi, tak lebih dari jaringan kutipan-kutipan, fragmen-fragmen tanda dan kodenya yang sudah ada sebelumnya, yang asal-muasalnya sudah tidak jelas lagi.

Penelitian ini mengangkat iklan rokok sebagai unit observasi. Peneliti merasa tertarik terhadap hal ini karena didasari keingintahuan tentang bagaimana sebuah iklan rokok mengangkat tema-tema tertentu dan mengaitkannya dengan ideologi tertentu pula. Iklan rokok yang hendak diobservasi atau diamati adalah iklan televisi rokok 'Djarum Super'. Berdasarkan pertimbanganpertimbangan tersebut, peneliti memilih mengkaji iklan rokok yang dimuat di televisi dalam kurun waktu Bulan Juni 2009. Peneliti memilih tiga film iklan 'Djarum Super' pada bulan ini, yakni versi 'Olahraga Petualangan', versi 'Sepakbola' dan versi 'Bulu Tangkis'.

\section{Mitos Lelaki sebagai Makhluk Bebas}

Salah satu mitos yang direpresentasikan oleh iklan rokok Djarum Super adalah lelaki yang merupakan makhluk yang bebas. Mitos ini direpresentasikan dalam TVC Djarum Super versi 'Olahraga Petualangan' pada adegan pesawat gantole.

Scene menggambarkan tiga buah jip dengan beberapa penumpang laki-laki di dalamnya yang sedang melaju di padang pasir sambil mengangkut pesawat gantole. Teknik pengambilan gambar secara longshot dipakai kameraman untuk menggambarkan latar belakang padang pasir yang dilalui ketiga jip tersebut. Tidak lupa, permainan warna kontras antara langit yang biru, padang pasir, sinar matahari, serta warna merah ketiga gantole tersebut.

Gantole atau dalam bahasa Inggrisnya hang-gliding bukan merupakan kendaraan komersial, melainkan kendaraan yang digunakan sekedar untuk hobi saja. Hanggliding merupakan salah satu bentuk olahraga cabang dari paralayang. Olahraga ini menggunakan pesawat yang tidak bermesin yang diberi nama hang-glider. Nama Gantole sendiri diambil dari bahasa Bugis yang berarti capung (id.wikipedia.org).

Olahraga Gantole merupakan olahraga yang mewah. Mewahnya olahraga ini dika renakan mewahnya peralatan yang diperlukan, sehingga dapat disimpulkan bahwa orang-orang yang memainkannya merupakan orang yang berkecukupan secara finansial.

Gantole sendiri merupakan olahraga yang cukup berisiko. Bahkan konon, di awal penemuan gantole pada abad ke-4, orangorang yang diperintahkan kaisar China untuk mencoba 'alat baru yang bisa terbang', ba nyak yang menemui ajalnya karena terjatuh dari ketinggian. (id.wikipedia.org).

Secara umum dapat disimpulkan bahwa setidaknya ada tiga aspek penting olahraga gantole ini. Pertama, gantole adalah olahraga yang memerlukan tingkat keterampilan tinggi. Kedua, gantole adalah olahraga yang mewah. Dan ketiga, gantole merupakan olahraga yang cukup berisiko dan memerlukan keberanian. 


\section{Gambar 1.}

Peta Bekerjanya Tanda pada Adegan 'Pesawat Gantole'

\begin{tabular}{|c|c|}
\hline $\begin{array}{c}\text { Penanda (Denotatif) } \\
\text { Gambar tiga buah pesawat gantole } \\
\text { dinaikkan di atas tiga buah jip yang } \\
\text { berisi sekelompok lelaki sedang } \\
\text { meluncur diatas padang pasir }\end{array}$ & $\begin{array}{c}\text { Petanda (Denotatif) } \\
\text { Tiga buah pesawat gantole yang } \\
\text { dinaikkan di atas tiga buah jip yang } \\
\text { berisi sekelompok lelaki sedang } \\
\text { meluncur diatas padang pasir }\end{array}$ \\
\hline \multicolumn{2}{|c|}{$\begin{array}{c}\text { Tanda (Denotatif) } \\
\text { Sekelompok lelaki hendak melakukan kegiatan layang gantung atau hang-gliding }\end{array}$} \\
\hline \multicolumn{2}{|c|}{$\begin{array}{l}\text { Tanda Konotasi } \\
\text { Lelaki yang merasakan kebebasan di angkasa }\end{array}$} \\
\hline Lelaki ada & khluk bebas \\
\hline
\end{tabular}

Tanda-tanda visual scene gantole ini membawa pesan-pesan yang dapat kita lihat dengan bantuan kode hermeneutik pada aspek enigma. Pertanyaannya, mengapa kendaraan yang dipilih adalah pesawat gantole? Kemudian kenapa setting adegan itu adalah padang pasir?

Gantole merupakan pesawat terbang sederhana. Gantole mirip dengan konsepkonsep pesawat terbang yang pertama, pesawat yang tidak mengandalkan kekuatan mesin. Gantole lebih mengandalkan kemampuan pilot, serta kekuatan angin untuk menerbangkan pesawat. Dengan demikian, pilot tidak terpancang untuk memenuhi prosedur tertentu yang rumit, mengendarai gantole tidak membutuhkan energi, hanya mencari arah angin saja, tidak melalui jalurjalur tertentu sebagaimana dilakukan di darat dan sebagainya. Pilot lebih terbebaskan untuk menerbangkan pesawat gantole sesuai keinginannya. Pilot lebih bebas.

Menaiki pesawat gantole, pilot dapat merasa terbang seperti burung. Gantole bergerak secara bebas di angkasa, tidak bermesin, dan melayang-layang seperti burung. Pengendara gantole dibebaskan dari aktivitas berjalan kaki yang memakan energi, atau dibebaskan dari berkendaraan di darat yang harus melalui jalur-jalur tertentu.
Padang pasir merupakan dataran luas tanpa batas. Di padang pasir tidak dijumpai pohon, bahkan batu-batuan juga sedikit jumlahnya. Padang pasir membebaskan orang melihat dengan hampir tidak berbatas, batasnya hanya cakrawala. Di padang pasir orang bebas bergerak kemana pun tanpa khawatir menabrak sesuatu. Dengan demikian, padang pasir mencerminkan kebebasan bergerak manusia di daratan, sebagaimana bebasnya pergerakan burung di angkasa.

Unsur manusia dan pesawat gantole merupakan dua unsur yang berbeda. Keduanya disatukan dalam adegan ini. Apabila dikaji dengan menggunakan kode simbolik, yakni aspek kemenduaan dan pertentangan dua unsur, maka akan dijumpai persandingan kedua unsur tersebut. Manusia adalah makhluk yang berjalan di darat, dilingkupi oleh aturan-aturan gravitasi. Sedangkan, pesawat gantole adalah simbolisasi makhluk udara, di mana aturanaturan gravitasi bumi hanya sedikit melingkupinya. Kedua unsur yang berbeda tersebut disatukan, dan kemudian memunculkan makna baru mengenai kebebasan manusia.

Mitos yang direpresentasikan dalam scene iklan ini : Lelaki adalah Makhluk 
Bebas. Lelaki tidak dikendalikan oleh apapun. Lelaki justru mengendalikan apapun. Dengan kata lain, seorang lelaki yang belum atau tidak mendapatkan kebebasannya dikatakan belum atau tidak laki-laki. Lelaki itu belum sempurna, belum memenuhi standar maskulinitasnya.

Dalam kehidupan sehari-hari, lelaki yang maskulin harus bisa bebas dari tekanan peraturan yang mengekangnya. Ketika ada acara lamaran pernikahan, lelaki cenderung menjadi pemilih daripada yang dipilih, sementara perempuan berada pada posisi dipilih. Apabila ada kasus di mana lelaki menjadi pihak yang dipilih, atau lelaki dipilihkan oleh orang lain, maka lelaki tersebut dianggap kurang maskulin. Kejadian ini berlanjut ketika pasangan tersebut melanjutkan hubungannya dalam rumah tangga, lelaki bebas menentukan arah rumah tangga berjalan, sedangkan perempuan cenderung hanya menjadi pengikut saja.

Bidang ekonomi rumah tangga juga berada pada kungkungan maskulinitas lelaki. Ketika lelaki punya uang, ia berhak memutuskan sendiri (tanpa perundingan dengan isteri) kegunaan uang itu. Maka wajar-wajar saja apabila uang belanja seharihari lebih rendah daripada uang rokok seharihari. Itu adalah lelaki maskulin. Ketika perempuan bekerja, maka fungsi ekonominya hanya sebagai pembantu ekonomi keluarga, bukan untuk dirinya sendiri. Itu wajar-wajar saja, dan itulah maskulinitas yang sebenarnya.

\section{Mitos Lelaki sebagai Makhluk Publik}

Iklan televisi Djarum Super juga merepresentasikan mitos lelaki sebagai makhluk publik, yang secara implisit dapat dimaknai juga bahwa wanita merupakan makhluk domestik. Mitos ini direpresentasikan dalam iklan televisi versi 'Olahraga Petualangan' pada adegan 'Kano'.

Adegan dimulai dengan pengambilan gambar secara close up sebuah dayung yang sedang dipakai mengayuh. Adegan berpindah menunjukkan lima orang laki-laki yang sedang mengayuh perahu/ kano secara bersama-sama dengan salah satunya membawa sebuah lentera.
Kano dapat didefinisikan sebagai perahu ukuran kecil, biasanya menggunakan penggerak utama tenaga manusia, walaupun kadangkala ada juga yang memanfaatkan tenaga angin atau motor. Bentuk kano seringkali melancip pada kedua ujungnya, serta terbuka bagian atasnya (tanpa atap). Daya angkut kano modern biasanya hanya untuk dua orang, adapun kano tradisional mampu mengangkut hingga 20 orang (en.wikipedia.org).

Pada sebagian masyarakat yang berada di dekat sungai, kano digunakan untuk aktivitas sehari-hari. Di beberapa tempat bahkan digunakan sebagai pasar mengapung, ketika transaksi perdagangan dilakukan di atas kano / perahu kecil. Kano juga dijadikan ajang kompetisi dalam olahraga-olahraga air. Selain kano, perahu jenis ini disebut juga sebagai kayak. Perbedaan antara kano dan kayak hanya pada posisi duduk pengayuhnya, apabila pengayuh kano posisinya seperti orang berlutut, sedangkan pengayuh kayak seperti orang selonjor.

Laki-laki digambarkan dalam adegan tesebut selalu bekerjasama dengan teman, dan mempunyai banyak aktivitas yang berkaitan dengan orang lain, yang di dalam iklan digambarkan sebagai sesama laki-laki. Secara implisit iklan ini menyatakan bahwa laki-laki maskulin tidak seperti perempuan. Perempuan adalah sosok makhluk yang tidak mempunyai teman dan tidak pantas mempunyai teman. Bahkan, perempuan kadangkala hanya mempunyai sosok suami dan anak saja sebagai teman, lainnya tidak.

Secara implisit pula, adegan iklan ini berbicara tentang peran publik dan domestik. Bahwa lelaki adalah makhluk yang 'berkuasa' di ranah publik, sedangkan perempuan merupakan makhluk yang berada di ranah domestik. Relasi-relasi lelaki dengan temantemannya yang direpresentasikan sedang mengayuh kano menggambarkan kerjasama para lelaki untuk mencapai tujuan hidupnya dengan mengabaikan peran perempuan yang bersifat lebih sebagai 'teman belakang' saja. Representasi serta mitos yang dimunculkan iklan versi 'Olahraga Petualangan' dalam adegan 'Kano' dapat dilihat dalam peta bekerjanya tanda berikut ini: 


\section{Gambar 2}

Peta Bekerjanya Tanda pada Adegan 'Kano'

\begin{tabular}{|c|c|}
\hline $\begin{array}{c}\text { Penanda (Denotatif) } \\
\text { Gambar lima orang lelaki } \\
\text { mengendarai perahu kano, } \\
\text { membawa dua buah lentera } \\
\text { menuju ke sebuah dasar air terjun }\end{array}$ & $\begin{array}{c}\text { Petanda (Denotatif) } \\
\text { Lima orang lelaki mengendarai perahu } \\
\text { kano, membawa dua buah lentera } \\
\text { menuju ke sebuah dasar air terjun }\end{array}$ \\
\hline \multicolumn{2}{|c|}{$\begin{array}{c}\text { Tanda (Denotatif) } \\
\text { Sekelompok lelaki hendak menuju air terjun dengan menggunakan perahu } \\
\text { kano }\end{array}$} \\
\hline \multicolumn{2}{|c|}{$\begin{array}{c}\text { Tanda Konotasi } \\
\text { Sekelompok lelaki bekerjasama untuk mencapai tujuan } \\
\end{array}$} \\
\hline Lelaki adalah & $\begin{array}{l}\text { Yitos } \\
\text { akhluk sosial/publik }\end{array}$ \\
\hline
\end{tabular}

\section{Mitos Lelaki adalah Pemimpin / Penguasa}

Iklan Djarum Super yang diteliti selanjutnya adalah versi 'Sepakbola'. Jalinan cerita dalam film iklan Djarum Super versi Sepakbola dimulai dengan sinar matahari yang cerah di langit yang kebiruan. Tidak berapa lama kemudian, sebuah bola jatuh ke dalam air. Ternyata, sudut pandang penonton iklan dibawa ke dalam air, dan posisi penonton seperti sedang melihat langit biru dengan matahari bersinarnya dari bawah air. Kedatangan bola secara tiba-tiba menyadarkan penonton iklan mengenai posisinya yang sedang berada di bawah air.

Bola tersebut kemudian disambut seorang pemain berseragam biru kombinasi merah dengan sundulan. Bola itu kemudian mengarah ke pemain lain yang berseragam biru kombinasi putih, pemain itu mengontrolnya dengan menggunakan dada, sejenak kemudian bola mengarah ke kakinya, lalu dipermainkannya dengan teknik juggling yang bagus.

Adegan berpindah pada pemain lain yang berseragam hijau muda. Pemain itu melakukan operan dengan menggunakan kaki kanannya, atau lazim disebut passing. Operan diterima oleh seorang pemain lain yang berseragam kuning bercelana hitam, kemudian dia memamerkan kemampuannya mengolah bola dengan kaki atau dribbling.

Bola berpindah lagi, kali ini kepada pemain yang berkostum kombinasi merah putih dan bercelana biru. Pemain itu memeragakan teknik mengontrol bola menggunakan bagian dadanya. Sekejap bola kembali lagi kepada pemain berkostum biru kombinasi putih. Dengan menggunakan lututnya, pemain itu mengarahkan bola ke atas kepalanya, lalu disundulnya bola itu dengan keras. Bola tidak dapat dijangkau oleh kiper, dan terjadilah gol. Pemain yang membuat gol itu merayakannya dengan ekspresi wajah gembira bercampur puas dan tangan mengepal keatas.

Adegan beralih pada dua pemain, masing-masing berseragam biru kombinasi merah dan berseragam kuning bercelana hitam. Tampaknya kedua pemain itu tengah berebut bola. Kemudian datang pemain berseragam hijau muda. Akhirnya mereka bertiga saling berebut bola menggunakan teknik tingkat tinggi. Diakhiri dengan tembakan bola oleh pemain berkostum kuning bercelana hitam. Bola bergerak keras ke atas, berhenti di permukaan air dan berotasi di sana, di bawah rangkaian tulisan DJARUM 


\section{Gambar 3}

Peta Bekerjanya Tanda Pada Adegan "Bola Masuk Air"

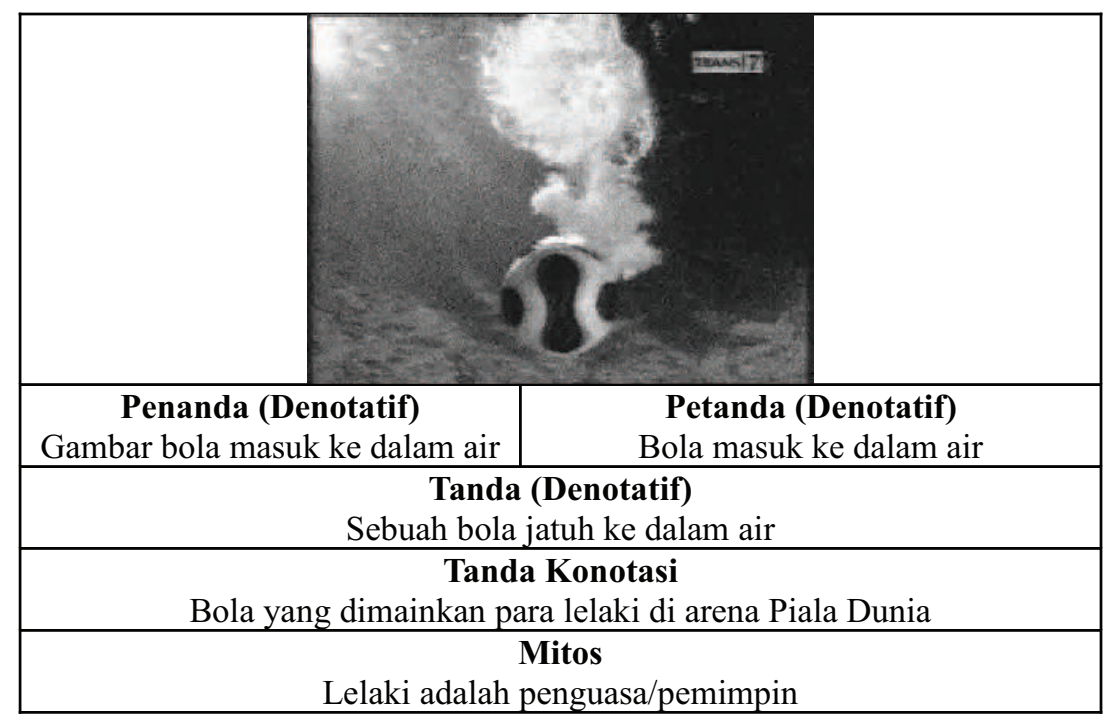

SUPER SOCCER, yang berwarna keemasan pada 'Djarum Super', dan berwarna putih pada tulisan 'Soccer'. Tidak lupa terdapat logo bujursangkar berwarna merah kombinasi kuning dan hitam, khas iklan Djarum Super.

Secara khusus, mitos lelaki merupakan pemimpin, atau penguasa dapat dilihat pada adegan 'Bola Masuk Air'. Peta bekerjanya tanda pada adegan ini tampak pada gambar 3 .

Sekilas tampak tidak ada yang istimewa dalam adegan ini. Teknik kamera hanya menggunakan mid-shot tanpa gerakangerakan berarti. Hanya saja, pemilihan bola sebagai foreground dan lingkungan air serta langit sebagai background menimbulkan penafsiran berbeda. Tampaknya, pembuat iklan ingin memberikan fokus pada sosok bola secara intens. Warna bola yang merah akan tampak kontras dengan warna air dan langit yang biru. Akhirnya, pembaca dapat melihat bahwa yang hendak ditampilkan dalam iklan tersebut adalah semua hal yang berkaitan dengan dunia bola.

Adapun sound yang digunakan adalah kombinasi sound effect dan drum yang ditata sedemikian rupa sehingga menjadi semacam musik intro atau pengiring. Ketika bola masuk ke dalam air, spontan suara drum menggema seakan hendak menekankan dramatisasi ketenangan yang terkoyak.

Tidak ada sosok lelaki dalam potongan adegan ini, yang ada hanya sebuah bola. Tampaknya bola itu bukan sembarang bola. Dari penelusuran peneliti, bola itu ternyata adalah bola yang digunakan dalam pertandingan besar Piala Dunia 2006, yang diselenggarakan di Jerman. Bola itu merupakan varian dari Adidas Teamgeist. Adapun bola yang dipergunakan dalam iklan itu dinamakan sebagai Adidas +Teamgeist LF. Bola Adidas Teamgeist ini sangat terkenal pada tahun 2006 itu. Bahkan, sampai sekarang pun masih sering digunakan dalam pertandingan-pertandingan resmi. Salah satu perusahaan game, yakni Konami, menggunakan varian Adidas + Teamgeist LF dalam game-nya yang dirilis pada tahun 2007, yakni Pro Evolution Soccer 2008 (PES2008).

Tanda plus $(+)$ pada kata + Teamgeist dibubuhkan sebagai tanda trade mark dari merek tersebut. Teamgeist sendiri merupakan Bahasa Jerman yang artinya kurang lebih semangat tim (team spirit), dan tentu saja tidak bisa dijadikan merek dagang. Bola ini didesain olah Adidas Innovation Team dan Molten Corporation. Menurut Adidas, bola ini memiliki beberapa kelebihan teknologi diban dingkan bola-bola produksinya yang terdahulu. Diantara beberapa kelebihan yang diklaim oleh Adidas adalah: (1) merupakan bola yang paling bulat yang pernah diproduksi, (2) merupakan bola yang paling anti air 
dibandingkan produk sebelumnya, karena sedikitnya lem dan celah dalam bola itu, (3) menggunakan teknologi pengikat thermal, dan (4) hanya mempunyai 14 panel kulit (sebelumnya ada 32 panel), yang membantu mempertahankan bentuk bola.

Pemilihan bola yang dipakai dalam Piala Dunia 2006 tersebut tentu saja membawa ideologi maskulinitas di dalamnya. Piala Dunia sebagai kompetisi sepakbola terbesar di planet ini merupakan kata kuncinya. Piala Dunia hingga saat ini masih di miliki oleh kaum lelaki. Sepakbola, bagaimanapun, hampir selalu diidentifikasi dengan maskulinitas. Kelelakian. Sepakbola yang membuat seorang lelaki tampak lebih lelaki. Ikut campurnya "yang bukan lelaki" dianggap sebagai sesuatu yang unik, aneh, disambut berlebihan, kadang-kadang dipandang sebelah mata.

'Kelelakian' dalam sepakbola mendapatkan momentum puncaknya pada kompetisi Piala Dunia. Di ajang ini para lelaki menikmati kekuasaannya, menguasai pandangan para manusia, menyihir hampir 70 persen penduduk dunia. Sehingga, supremasi lelaki tersebut dicerminkan dalam bola yang digunakannya, + Teamgeist.

Kode hermeneutik tampak di dalam iklan ini dengan munculnya pertanyaan tentang masuknya bola ke dalam air. Mengapa bola itu harus masuk ke dalam air? Mengapa tidak di darat saja, atau di lapangan sebagaimana realitas yang kita jumpai seharihari?

Tampaknya, pengiklan memilih air sebagai media bermain bola bukannya tanpa sebab. Pertama, air itu bukan habitat alami manusia. Banyak keterbatasan manusia dalam air; manusia tidak dapat bernapas dalam air, susah menggerakkan dalam air, dan sebagainya. Sepak bola merupakan olahraga yang berat, dan membutuhkan stamina fisik yang prima. Ini ditandai dengan terbatasnya usia pemain sepakbola yang rata-rata berada pada kisaran 17 hingga 35 tahun. Sepak bola yang dilakukan di darat saja sudah berat, apalagi yang dilakukan di dalam air, pasti lebih berat lagi. Iklan 'Djarum Super' membuat olahraga sepak bola menjadi lebih 'berat', butuh orang dengan kekuatan lebih untuk memainkan olahraga sepak bola ala Djarum Super.

Kedua, air adalah tempat yang dingin. Rata-rata suhu air normal lebih rendah daripada suhu darat. Pesan yang disampaikan iklan Djarum Super tampaknya mengarah kepada situasi sepak bola pada umumnya. Sepak bola diharapkan tetap menjadi olahraga yang 'dingin'. Olahraga yang tidak disertai keributan, amuk massa, perang antarsuporter, dan sebagainya. Permusuhan sepak bola cukup di lapangan saja, tidak perlu melebar hingga keluar lapangan. Pesan ini tampaknya menyikapi situasi persepakbolaan tanah air yang sering diwarnai dengan keributan, tawuran, dan hal-hal lain yang tidak hanya merugikan citra persepakbolaan, namun juga merugikan masyarakat umum.

\section{Mitos Lelaki sebagai Pengubah Dunia}

Iklan Djarum Super versi 'Bulu Tangkis' merepresentasikan mitos lelaki sebagai pengubah dunia, khususnya ketika adegan smash. Jalinan cerita iklan Djarum Super versi 'Bulu Tangkis' dimulai dengan adegan laki-laki dan perempuan yang sedang duduk santai sambil menonton televisi. Tibatiba mereka dikejutkan dengan adanya teriakan yang berasal dari jendela. Selanjutnya muncullah sesosok manusia (laki-laki) dalam keadaan seperti terlempar menerobos masuk melalui jendela. Laki-laki itu akhirnya terjatuh dan menimpa meja kaca mereka hingga pecah berantakan.

Adegan berikutnya mengambil latar belakang jalan raya. Ketika itu, lampu merah sedang menyala, dan kendaraan sedang antri dengan tertib menunggu kesempatan untuk jalan. Tiba-tiba terdengar suara teriakan (lakilaki), kemudian diiringi jatuhnya seorang laki-laki tepat di jalur zebra cross. Laki-laki yang mengenakan pakaian merah itu tampak sangat bergembira sekali, wajahnya tampak mengekspresikan kegirangan, dan dia menggerak-gerakkan syalnya.

Adegan ketiga dimulai dengan jatuhnya sesosok laki-laki yang juga sangat gembira. Laki-laki tersebut jatuh dan tersangkut di atas pohon. Di bawah pohon itu ada tiga perempuan terheran-heran melihat 
tingkahnya. Ketika mereka membalikkan badan, tampak sebuah stadion yang penuh dengan orang-orang yang juga terpelanting sebagaimana laki-laki di hadapan mereka.

Adegan berikutnya menampilkan seorang laki-laki yang hendak melakukan smash dengan raketnya. Laki-laki itu meloncat tinggi, bola di smash, dan muncullah efek ledakan yang hebat. Saking hebatnya ledakan itu, pemain lawan dan penonton yang ada di belakangnya terpental semua. Sehingga, dapat disimpulkan bahwa smash-smash itulah yang menyebabkan banyak orang terpental dari stadion.

Iklan ditutup dengan munculnya tulisan "JADILAH SAKSI KEDAHSYATANNYA", dengan huruf berwarna putih, serta latar belakang berwarna merah. Kemudian muncullah logo "DJARUM INDONESIA OPEN 2009", beserta jadwal dan tempat berlangsungnya pertandingan.

Pada iklan ini, peneliti menekankan meneliti lebih dalam pada adegan 'Smash'. Satu hal yang menarik dari adegan ini, yakni adanya efek dramatisasi. Efek dramatisasi dilakukan dengan memperlambat gerakan orang yang hendak melakukan smash, atau dikenal dengan slow motion. Tampaknya pembuat iklan ingin menampilkan detail gerakan smash tersebut. Uniknya, ketika smash dilakukan dan efek ledakan terjadi, gerakan gambar dicepatkan atau dikenal dengan fast motion.

Permainan bulu tangkis atau badminton, sudah dikenal manusia sejak lama. Setidaknya, olahraga ini telah ada semenjak jaman Yunani Kuno. Di Jepang, permainan Hanetsuki yang mirip bulu tangkis, telah ada sejak abad ke-16. Di dunia barat, bulu tangkis berasal dari permainan yang dinamai battledore and shuttlecock, di mana dua atau lebih pemain berusaha menahan agar shuttlecock tidak jatuh ke tanah dengan menggunakan raket kecil (en.wikipedia.org).

Bentuk modern bulu tangkis ditemukan di India, ketika militer Inggris yang menjajah negara itu pada akhir abad ke-19 tertarik dengan permainan mirip bulu tangkis yang dinamai permainan Poona. Versi lain penemuan permainan ini adalah dari kota Tanjore, India Selatan, pada tahun 1850. Di daerah tersebut terdapat sebuah permainan mirip bulu tangkis yang dikenal dengan nama pooppanthu vilayattam, merupakan bahasa Tamil yang berarti permainan bola-bunga. Bola yang digunakan dalam permainan ini sudah terbuat dari wol dan karton, bahanbahan yang digunakan pula dalam shuttlecock moderen.

Perkembangan bulu tangkis selanjutnya berada di negara Inggris. Namun, walaupun berkembang di Inggris, kompetisi bulu tangkis didominasi negara-negara seperti Denmark, Indonesia, Korea Selatan, dan Malaysia, yang secara konsisten memunculkan pemain-pemain kelas dunia. Beberapa tahun belakangan China masuk menjadi salah satu negara yang mendominasi permainan ini.

Smash merupakan salah satu senjata mematikan dalam permainan bulu tangkis. Pemain ganda putra dari China, Fu Haifeng, mencatatkan rekor smash dunia dengan kecepatan 332 km/jam pada 3 Juni 2005 pada turnamen Piala Sudirman. Sementara Taufik Hidayat membukukan rekor dunia smash pada nomor tunggal putra, dengan kecepatan $305 \mathrm{~km} / \mathrm{jam}$ (en.wikipedia.org).

Kedahsyatan smash digambarkan dengan adanya ledakan yang melemparkan pemain lawan dan para penonton. Smash dikatakan oleh iklan tersebut sebagai sesuatu yang mengubah pertandingan, dan mengubah kegembiraan penonton yang berada di pinggir lapangan.

Mitos yang ada dalam iklan ini bahwa: lelaki adalah pengubah dunia. Segala sesuatunya tidak akan berubah apabila tidak ada lelaki di dalamnya. Lelaki dibutuhkan untuk perubahan. Masyarakat yang dipimpin oleh seorang lelaki misalnya akan mengalami perubahan yang signifikan dibandingkan masyarakat yang dipimpin oleh perempuan. Berikut gambar peta bekerjanya tanda dalam adegan 'smash': 


\section{Gambar 4}

Peta Bekerjanya Tanda Dalam Adegan "Smash"

\begin{tabular}{|l|}
\hline Petanda (Denotatif) \\
Gambar seorang atlit bulu \\
tangkis lelaki melakukan aksi \\
smash
\end{tabular}

Lelaki sebagai pengubah dunia juga banyak dilegendakan, seperti misal kepemimpinan Mahapatih Gadjah Mada yang sukses menaklukkan Nusantara. Kemudian legenda Bandung Bandawasa yang harusnya mampu mengubah dunia, tapi karena 'pengaruh buruk' Roro Jonggrang, hasratnya mengubah dunia hilang. Roro Jonggrang yang dianggap membawa sial diubah oleh Bandung Bandawasa menjadi patung.

\section{Narsisisme Melalui Iklan}

Ketiga iklan Djarum Super tersebut menggunakan model utama lelaki. Rata-rata model lelaki yang dipakai adalah model anonim, artinya model yang tidak banyak dikenal oleh publik, bukan model selebritis. Adapun iklan 'Djarum Super' versi 'Bulu Tangkis' juga menyertakan model perempuan di dalamnya, namun hanya dalam kapasitas 'penonton' saja. Model perempuan ini seakanakan hanya menjadi pemanis iklan dan diposisikan sebagai penggembira para lelaki. Para perempuan ini hanya terheran-heran melihat lelaki dengan berbagai kemampuan dan kecuekannya.
Karakter model lelaki yang dimunculkan dalam iklan ini adalah para lelaki yang atletis. Atletis yang dimaksud di sini bukan berarti atletis yang harus berotot, akan tetapi lebih cenderung atletis dari segi tindakannya. Misalnya saja, seorang lelaki yang berani memanjat tebing tanpa alat apapun, atau lelaki yang melakukan smash dengan keras.

Namun, bukan berarti karakter itu tidak didukung oleh karakter fisik tertentu. Iklan tersebut, misalnya, menunjukkan wajahwajah lelaki dan perempuan yang rata-rata berwajah rupawan, serta tentu saja muda. Atribut-atribut tersebut setidak-tidaknya mencerminkan pemujaan tubuh di dalamnya.

Piliang mengatakan hal ini sebagai citra narsistik (Kompas, 17/01/09). Narsisisme ini tidak sekadar diartikan sebagai kecenderungan pencarian kepuasan seksual melalui tubuh sendiri (Freud), tetapi juga segala bentuk "penyanjungan diri" (self admiration), "pemuasan diri" (selfsatisfaction), atau pemujaan diri (selfglorification) (Erich Fromm), atau segala kecenderungan melihat dunia sebagai cermin atau proyeksi dari ketakutan dan hasrat 
seseorang.

Para lelaki dalam iklan tersebut seakan hendak mengatakan kepada dunia mengenai keasyikannya kepada diri sendiri. Mayoritas adegan dalam iklan tersebut menggambarkan lelaki yang tidak perlu menatap kamera. Menurut Williamson (2007:121) lelaki seperti ini telah 'melepaskan diri dari semuanya', dengan semua kegiatannya; pengasingannya, kemandirian dan maskulinitasnya di sini. Lelaki seperti ini tidak perlu melihat kepada pemirsa, karena sang pemirsalah yang melihat kepadanya. Dia tidak melihat ke luar iklan. Dia tidak harus mencari-cari, tidak harus menyenangkan pemirsa; dia akan melayangkan tatapannya pada apa pun yang memikatnya, dalam hal ini kegiatan maskulinnya.

Selain itu, iklan ini juga menunjukkan orang-orang yang dianggap sebagai 'sahabatsahabat konsumen', menyapa konsumen sebagai individu, dan menariknya masuk ke dalam suatu kelompok tertentu. Terjadi sebuah pertukaran di sini, person yang dirujuk iklan (konsumen, audiens), dengan person yang berada dalam iklan. Sekelompok orang yang mengisap rokok Djarum Super, diidentifikasikan sebagai orang yang ditampilkan dalam iklan tersebut. Dipertukarkannya konsumen / audiens dengan orang-orang yang berada di dalam iklan menuntun kepada ide tentang 'fase cermin' (Williamson: 2007: 65).

Dengan demikian, hal yang jelas dilakukan iklan adalah menandakan, merepresentasikan kepada konsumen, objek hasrat. Karena objek tersebut adalah sang diri, ini berarti bahwa, sembari menjerat/menciptakan subjek melalui pertukaran tanda-tanda yang dilakukan subjek (laki-laki atau perempuan), iklan tersebut sebenarnya membesarkan 'hasrat subjek akan koherensi dan makna itu sendiri' di dalam dirinya. Hal ini seolah-olah merupakan penyuplaian kekuatan yang menggerakkan semua mesin iklan, dan harus diakui begitu saja.

Teori psikoanalitik Lacan menjadi penting karena ia melihat kesadaran sebagai tercipta dan bukan inheren: subjek itu dibentuk, bukan bawaan. Ide tentang penciptaan 'kesadaran' secara jelas berhubungan dengan proses ideologis (dalam Williamson, 2007:86).

Poros Imajiner dan Simbolik adalah 'fase cermin'. Teori fase cermin dikembangkan dari pelbagai pengamatan terhadap anak-anak di depan cermin. Relasi si anak terhadap imaji-cerminnya melibatkan dua persepsi yang berlawanan. Pertama, bahwa dia dan imaji itu adalah sama; pada tataran imajiner, hambatan cermin dihancurkan dan terdapat aliran identitas antara diri si anak, dan representasinya, yaitu imaji diri. Kesatuan imajiner ini adalah EgoIdeal. Namun secara paradoks, agar imaji ini merepresentasikan diri 'yang padu', ia harus terbelah dari diri tersebut, sebab suatu tanda harus menandakan sesuatu; dan karena imaji itu 'memaksudkan' dia, maka imaji itu tak pelak lagi tidak bisa menjadi dia. Jadi, dua area terbentuk: area tempat eksisnya kesamaan, yaitu area imajiner; dan area tempat eksisnya perbedaan, yaitu area simbolik.

Dengan demikian, imaji cermin dapat dipandang sebagai penanda diri yang kosong; karena keberjarakannya sekaligus keserupaannya, ia menyuguhkan bentuk dari suatu tanda, hanya saja suatu tanda yang bohong tanpa isi. Imaji cermin dapat merepresentasikan si anak, namun sebelum dia sendiri terdiferensiasi dari yang lainnya, imaji tersebut tidak dapat merepresentasikan dia berkenaan dengan suatu identitas sosial, sebuah 'aku sosial'. Dia masih belum memiliki satu identitas, untuk direpresentasikan. Jadi, imaji cermin dapat menciptakan suatu sistem pertandaan identitas potensial anak, namun pada tahap ini, identitasnya sendiri tidak terdefinisikan, karena simbol tidak memiliki makna yang berbeda.

Istilah patriarki pada awalnya digunakan oleh Max Weber untuk mengacu ke sistem sosial politik tertentu di mana seorang ayah, berkat posisinya dalam rumah tangga, dapat mendominasi anggota keluarga dan menguasai produksi ekonomi dari kesatuan kekerabatan (Saptari dan Holzner, 1997: 48).

Patriarki merupakan sistem terstruktur 
dan praktek sosial yang menempatkan kaum laki laki sebagai fihak yang mendominasi, melakukan opresi dan mengeksploitasi kaum perempuan. Sistem ini ada dalam dua bentuk, yakni: private patriarchy (patriarki domestik) yang menekankan kerja dalam rumah tangga sebagai stereotipe perempuan, dan public patriarchy (patriarki publik) yang menyereotipkan laki laki sebagai pekerja di sektor sektor publik yang sarat dengan karakter keras penuh tantangan (Tomagola: 1998: 20). Kuatnya cengkeraman patriarki ini menyebabkan perempuan lebih banyak berada pada posisi marjinal dan sub ordinat dalam budaya kerja maskulin, karena posisi itu dibentuk oleh ideologi patriarkhi yang meneguhkan perempuan menjadi dominan dibidang sub ordinasi. Celakanya, menurut Abdilah (2001:192), ideologi yang memandang perempuan sebagai "makhluk lemah" telah menjadi ideologi umum yang tidak hanya memengaruhi masyarakat awam, tetapi juga menjadi cara pandang kaum intelektual dalam melihat dan menempatkan kaum perempuan.

Munculnya ideologi patriarkhi sebagai ideologi umum yang menjadi cara pandang masyarakat terhadap eksistensi perempuan, tidak terlepas dari cerita sejarah berkaitan dengan lahirnya perbedaan gender (gender differences) antara manusia laki laki dan manusia perempuan. Prosesnya panjang, dan perbedaan itu dikarenakan oleh banyak hal, diantaranya dibentuk, disosialisasikan, diperkuat, bahkan dikonstruksi secara sosial atau kultural, melalui ajaran moral dan adat istiadat, sehingga sosialisasi gender yang panjang itu akhirnya dianggap sebagai ketentuan Tuhan dan bersifat biologis yang tidak bisa diubah ubah lagi. Ini berarti bahwa perbedaan perbedaan gender itu telah dipersepsi sebagai kodrat laki laki dan kodrat perempuan yang harus diterima apa adanya.

Salah satu isi yang secara konsisten disajikan media adalah ideologi patriarki sebagai suatu istilah psikoanalisis the law of the father, yang masuk lewat kebudayaan lewat bahasa atau proses simbolik lainnya. Patriarki adalah relasi hierarkhis antara lelaki dan perempuan yang menempatkan lelaki lebih dominan daripada perempuan. Ideologi ini melahirkan perbedaan gender (gender differences) dan ketidakadilan gender (gender inequalities) yang dikonstruksi secara sosial maupun kultural melalui proses panjang dan seringkali dianggap sebagai ketentuan Tuhan dan seolah-olah bersifat kodrati, tidak dapat diubah lagi, sehingga sifat-sifat yang dilekatkan pada lelaki dan perempuan dianggap sebagai kodrat dan keharusan yang diperoleh sejak lahir (Fakih, 1999).

Representasi iklan televisi mungkin dapat dikatakan sebagai perpanjangan dari sistem kapitalisme, yang memang dirasakan menguntungkan bagi biro-biro periklanan, production house dan broadcasting house. Akan tetapi, apakah dengan kekuatan ekonomi dari pemilik modal (kapitalis) mereka dapat semaunya mengeksploitasi dan mendefinisikan gagasan tentang konstruksi sosial, yang di dalamnya termuat ekspektasi tentang manifestasi gender? Hal ini akan berpulang pada desainer dalam menangkap fenomena atau kode-kode sosial untuk ditransformasikan ke dalam proses berpikir kreatif yang digunakan sebagai mainstream ketika mereka memposisikan gagasan mengenai maskulinitas dan femininitas.

Dalam konsep berfikir kreatif, diskursus tentang gender ini memang terasa ikut memengaruhi kreativitas dalam berkarya. Ketika mereka memandang sentuhan estetika dengan menempatkan perempuan sebagai obyek dan subyek gender, hal ini akan masuk dalam rambu-rambu sosial yang di dalamnya banyak sekali sistem nilai yang ikut memengaruhi. Banyak interpretasi yang mengesankan subordinasi dan domestikasi dalam menyikapi beberapa representasi iklan televisi pada sisi normatif memang merujuk pada pemahaman gender inequalities. Akan tetapi tanggung jawab terhadap citra-citra tersebut tidak dapat hanya dibebankan langsung pada desainer, atau malah menjadikan keterbatasan dalam mengekspresikan estetika dalam berkesenian. Hal ini adalah tanggung jawab masyarakat bersama sebagai suatu komunitas budaya.

Ideologi patriarkhi masih menjadi latar belakang tampilan iklan rokok 'Djarum Super'. Citra stereotipe gender berdasarkan nilai-nilai lama peran sosial pria. Pria 
digambarkan sebagai makhluk nomor satu.

\section{Dominasi Kapitalisme}

Menurut perspektif strukturalisme, dunia budaya hari ini dikuasai oleh budaya kapitalisme melalui proses inkorporasi dan komodifikasi. Proyek ini bekerja dalam ruang kerja globalisasi dan pasar bebas, sehingga dapat disaksikan bagaimana seluruh dunia dan social space tersedot menuju sebuah model logika kerja budaya yang bernama kapitalisme.

Kapitalisme adalah sebuah sistem ekonomi yang dibentuk oleh kesadaran modern yang berpijak pada rasionalitas. Sebagai sistem ekonomi rasional, kapitalisme mengharuskan adanya akumulasi modal yang berlaku terus-menerus. Berbagai komoditi diciptakan demi menjaga stabilitas kemapanannya. Ilmu pengetahuan dan teknologi dikembangkan dengan maksimal sehingga dapat mendukung kepentingannya. Media massa dikuasai dan dijadikan alat untuk mengomunikasikan kepentingannya kepada masyarakat selaku konsumennya (Halim, 2002: 62-63).

Sistem kapitalisme global telah merasuk dalam berbagai bidang kehidupan, baik ekonomi, sosial, politik, budaya, agama, dan sebagainya. Hampir tidak ada satu wilayah pun yang tidak terjamah oleh pengaruh kapitalisme bahkan dalam wilayah privat sekalipun. Kapitalisme melakukan penetrasi ke dalam semua lini kehidupan manusia agar dapat semakin mengokohkan kekuasaannya sekaligus demi mencapai satu tujuan, yakni meningkatkan akumulasi kapital sebanyakbanyaknya. Atas nama kepentingan ini, komoditi diproduksi secara terus-menerus agar menghasilkan keuntungan ekonomis.

Dalam prakteknya di pasar (dan di manapun) selalu saja ada manusia-manusia yang bermoral tidak sehat. Di mana mengandalkan mekanisme "alamiah" tidak cukup mampu untuk mengobati ketidaksehatan tersebut. Ternyata walaupun kepada semua manusia diberikan kesempatan yang sama atau telah ada pemerataan dalam kesempatan berusaha, harus ada faktor lain yang juga perlu diperhatikan secara seksama.
Seperti kemampuan kreatifitas, perbedaan vitalitas dan dinamika, perbedaan kemampuan untuk bekerja secara lebih keras antar manusia, perbedaan kecerdasan dan kepandaian, perbedaan fasilitas, dan yang sangat penting adalah kapasitas di bidang moral. Maka, semua manusia yang sudah merata kesempatannya untuk berusaha, toh akhirnya akan ada saja upaya-upaya untuk berlaku tidak "fair" atau jujur, kotor dan mau menang sendiri. Setelah dia memperoleh kedudukan yang bersifat monopolistik misalnya, dia memiliki kemampuan dan kewenangan untuk menentukan harga, kualitas dan sebagainya seenaknya sendiri, demi kekayaannya sendiri. Karena bagaimanapun keadaan barang dan jasanya toh konsumen akan tetap membelinya.

Komodifikasi menurut perbendaharaan kata dalam istilah Marxist adalah suatu bentuk transformasi dari hubungan, yang awalnya terbebas dari hal-hal yang sifatnya diperdagangkan, menjadi hubungan yang sifatnya komersil. Dalam artian bahwa hubungan sosial terreduksi menjadi hubungan pertukaran. Komodifikasi juga merupakan istilah yang hanya ada dalam konsep jual-beli di tahun 1977, namun mengekspresikan konsep fundamental atas penjelasan Karl Marx tentang bagaimana kapitalisme terbangun.

Karl Marx dalam bukunya Communist Manifesto, mendefinisikan komodifikasi sebagai "Callous Cash Payment", yakni "pembayaran tunai yang tidak berperasaan". Ia menggambarkan bahwa kaum kapitalis yang mempunyai kontrol atas apapun telah mengubah nilai-nilai personal menjadi nilai tukar, mengubah hubungan sentimental dalam keluarga menjadi hubungan yang mempergunakan uang. Sehingga segala sesuatu tidak akan bernilai jika tidak mempunyai nilai tukar. Kemudian Marx terfokus pada komodifikasi dalam proses kerja, dimana dalam realitasnya, aktivitas pekerjaan yang dilakukan oleh masingmasing pekerja (kerja guna) telah bertransformasi menjadi kerja abstrak. Jadi dalam kerja abstrak, aktivitas kerja yang diperlakukan seolah tidak ada perbedaan kualitas untuk memudahkan pertukaran. 
Katakanlah pembuat arloji dengan pembuat sepatu. Mereka bekerja dengan kemampuan yang berbeda, dengan pengoperasian yang berbeda, dan tentunya dengan alat yang berbeda. Namun di dalam kerja abstrak, semua itu dianggap sama agar dapat dianggap seimbang untuk memudahkan pertukaran.

Komodifikasi mencakup beberapa hal. Pertama, sosialisasi dari pekerjaan. Misalnya saja pekerjaan-pekerjaan seperti mencuci, menyiapkan makanan, dan merawat anakanak kini diperjualbelikan di pasar. Banyak orang lebih suka menawarkan pekerjaanpekerjaan tersebut demi sejumlah uang daripada secara sukarela melakukannya dalam lembaga perkawinan.

Kedua, privatisasi dari pelayanan pemerintah. Misalnya saja pelayanan pemerintah seperti layanan pendidikan, kesehatan, serta fasilitas-fasilitas umum yang seharusnya dapat dinikmati secara gratis, pada kenyataannya orang diharuskan membayar untuk menikmatinya.

Ketiga, komersialisasi dari aktivitas ilmiah dan kultural. Misalnya saja aktivitasaktivitas ilmiah dan kultural tidak lagi murni bertujuan mengembangkan kehidupan manusia menjadi lebih baik, tetapi seringkali disusupi dengan tekanan-tekanan yang disampaikan melalui mekanisme pendanaan. Jadi segala bentuk aktivitas ilmiah dan budaya dilakukan semata-mata untuk tujuan komersial dibandingkan menonjolkan sisi human interest-nya.

Keempat, profesionalisasi dari olahraga amatir dan pelayanan. Misalnya saja, saat seorang olahragawan amatir hendak bertanding, maka ia berlatih dulu di pagi hari, tujuannya untuk mendapatkan sejumlah dana dari sponsor misalnya.

Kelima, korporatisasi dari organisasi. Hubungan internal antara pimpinan dan akuntabilitasnya digantikan dengan mekanisme anggaran dari perencanaan (planning) dan pengendalian (control). Keenam, servis dengan membayar fee yang menggantikan asosiasi dan kerjasama yang sifatnya sukarela. Misalnya saja, orang membantu mengangkat dan menurunkan barang di pasar secara gratis, saat ini telah dijadikan profesi, atau misalnya saja bantuan penyeberangan jalan yang saat ini juga telah menjadi profesi.

Masih banyak contoh komodifikasi lainnya. Misalnya pembelian paket game yang menggantikan permainan konvensional yang bebas biaya, kekayaan intelektual, hak cipta, hak paten, label harga yang ditempatkan dalam informasi dan pengetahuan di seluruh cabang ilmu pengetahuan, industri dan seni.

Secara paradoks, periklanan memromosikan komodifikasi dan sekaligus menyangkalnya. Sebagai contoh, periklanan menempatkan komoditas ke dalam keluarga. Misalnya dalam iklan televisi teh Sariwangi yang menggambarkan bahwa hangatnya teh Sariwangi sehangat keluarga. Hal ini menggantikan konsep nilai tukar dalam komodifikasi tadi, menjadi representasi dari momen kasih sayang dalam keluarga.

Ketika periklanan menggerakkan kekuatan dari komoditas untuk mempertinggi hubungan, sebaliknya periklanan sendiri menyembunyikan proses produksi dengan meniadakannya, membuatnya menjadi abstrak, atau menyisipkan estetika di dalamnya. Sebagai khalayak, kita hanya tahu tampilan luar dari suatu komoditas dalam sebuah iklan, tanpa pernah tahu bagaimana komoditas itu diproduksi. Misalnya saja iklan sebuah penyedap rasa yang menggunakan figur ibu yang tengah memasak makanan lezat untuk anaknya, tapi ternyata pada waktu itu penyedap rasa tersebut mengandung unsur babi dan dinyatakan tidak halal oleh MUI. Hal ini memperlihatkan bahwa semakin dalam periklanan menembus sudut dan celahcelah kehidupan sosial kita, maka semakin sulitlah untuk mengritik periklanan, berkaitan dengan proses komodifikasi tadi.

Baudrillard mengemukakan bahwa masyarakat sekarang adalah masyarakat diam, disebutnya sebagai massa yang diam. Massa yang diam inilah yang mendambakan tontonan secara terus menerus (Piliang, 1995:33). Dan pendapat ini menjadi jelas ketika Guy Debord menyebut masyarakat kapitalisme mutakhir sebagai masyarakat tontonan. Menurutnya sudah sejak lama kapitalisme memroduksi komoditi, sementara konsumsi berjalan dengan sendirinya. Tetapi 
kini di dalam masyarakat tontonan, memroduksi komoditi harus disertai dengan memroduksi tontonan. Tontonan ini oleh Piliang dijabarkan sebagai materi-materi yang hadir dalam iklan, brosur, pameran, window display, hadiah kuis, dan lain-lain.

Semua komoditi menjadi tontonan dan semua tontonan menjadi komoditi. Tontonan bukanlah sekumpulan citra-citra, melainkan hubungan sosial di antara orang-orang yang digubah lewat citraan-citraan. Menonton pertandingan sepakbola tidak lagi sekedar menikmati pertandingan olahraga itu sendiri, namun telah menjadi sekumpulan ritual-ritual yang dangkal tetapi telah membawa citra-citra luar biasa. Citra sekumpulan penggembira, citra-citra melalui lambang/logo tim-tim yang berlaga, kuis-kuis, hadiah-hadiah, perang baliho. Bahkan, kehadiran suporter telah menyadarkan kita bahwa sepakbola sendiri bukan tujuan utama, tetapi komoditi lain yang telah menjadi bagian tidak terpisahkan dari sepakbola.

Tanpa disadari pemirsa, telah terjadi suatu indoktrinasi oleh media televisi melalui iklan, program-program dan informasi beritanya. Manusia telah dikondisikan untuk haus akan tayangan-tayangan televisi, masyarakat saat ini telah menjadi masyarakat tayangan. Ritme-ritme kehidupannya telah diatur oleh program-program tayangan dengan semua yang menyertainya. Harus disadari bahwa pola-pola ini membuktikan keberhasilan suatu wacana kapitalisme.

Adapun dinamika ruang publik dapat dilihat dari posisi warga masyarakat sebagai warga yang disentuh atau merespon kekuasaan dari 3 ranah kekuatan, yaitu dalam lingkup kekuasaan negara (state), dalam lingkup kekuasaan kapitalisme pasar (market capitalism), dan kekuasaan kolektif sosial (communalism). Sebagai konsumen kekuasaan negara warga disentuh atau merespon kebijakan negara (public policy). Sementara dalam menghadapi kekuasaan kapitalisme pasar, warga masyarakat sebagai konsumen, yang dicerminkan dari nilai ekonomis warga bagi produsen dalam konteks kapitalisme. Dalam konteks kekuasaan kolektif, warga masyarakat menjadi massa yang kehilangan posisi personal, dikalahkan oleh homogenisasi yang berlangsung dalam komunalisme.

\section{KESIMPULAN}

Iklan dan semiotika komunikasi berkaitan dengan masalah komunikasi. Semiotika komunikasi mengupas unsur-unsur komunikasi melalui tanda-tanda yang menghasilkan makna. Iklan merupakan salah satu sarana komunikasi yang menyampaikan informasi mengenai sebuah produk serta sebagai sarana penyampaian ideologi. Ideologi adalah ide-ide gagasan yang merupakan manifestasi dari tanda-tanda yang disusun ke dalam suatu sistem pertandaan. Pada konteks penelitian ini, analisis semiotika merupakan suatu cara dan usaha memahami konstruksi dunia maskulin pria dalam iklan rokok.

Pemahaman terhadap tata ungkap visual iklan rokok Djarum Super versi 'Olahraga Petualangan', Sepakbola, dan Bulu Tangkis, di televisi yang kemudian dijadikan landasan interpretasi terhadap nilai ideologis dan kultural iklan tersebut, maka dapat ditarik tiga kesimpulan besar.

Maskulinitas dikonstruksi iklan TVC Djarum Super sebagai lelaki yang selalu menyukai kehidupan bebas, petualangan, keberanian. Selain itu, lelaki yang maskulin juga digambarkan mempunyai kekuatan, serta memiliki pergaulan sosial yang luas. Maskulinitas juga digambarkan sebagai lelaki yang melakukan kegiatan 'tidak biasa', kegiatan yang lebih memerlukan tenaga dan keterampilan lebih. Pria maskulin juga dikonstruksi sebagai pria yang mampu melindungi wanita, serta menjadi perhatian wanita dan lingkungan sekitarnya.

Mitos-mitos lelaki yang muncul dalam iklan Djarum Super versi 'Olahraga Petualangan': bahwa lelaki adalah makhluk bebas, makhluk kuat, makhluk sosial/publik, makhluk yang tenang, suka berpetualang, pemberani, dan sosok pengatur. Sementara dalam iklan Djarum Super versi 'Sepakbola', mitos yang muncul : lelaki adalah penguasa, suka pamer, pemenang, dan makhluk pejuang. Terakhir, mitos yang muncul dalam iklan 
Djarum Super versi 'Bulu Tangkis' bahwa: lelaki adalah pelindung, pusat perhatian, mempunyai kedudukan yang tinggi, dan pengubah dunia.

\begin{tabular}{lll}
\multicolumn{2}{c}{ Olahraga merupakan tema yang } \\
diangkat Djarum $\quad$ Super untuk
\end{tabular} merepresentasikan maskulinitas. Tema olahraga merupakan tema yang sangat tepat untuk merepresentasikan mitos-mitos maskulinitas tersebut. Dunia olahraga selalu membutuhkan pemenang, dan selalu ada yang kalah juga dalam dunia olahraga ini. Pemenang dalam kegiatan olahraga merupakan lelaki maskulin, sementara yang kalah tidak. Bahkan, hanya lelaki maskulin yang berani melakukan sebuah olahraga tertentu. Karena hanya lelaki maskulin yang berani mengambil risiko untuk menjadi pemenang.

\section{DAFTAR PUSTAKA}

Abdilah, Ubed. 2002. Politik Identitas Etnis, Pergulatan Tanda tanpa Identitas. Magelang : Indonesia Tera.

Barthes, Roland. 2007. Membedah MitosMitos Budaya Massa: Semiotika atau Sosiologi Tanda, Simbol, dan Representasi. Penerjemah: Ikramullah Mahyuddin. Penyunting : Yosal Iriantara dan Dede Lilis Ch, Subandy. Bandung : Jalasutra.

Budiman, Kris. 2000. Feminis Laki-Laki dan Wacana Gender. Magelang : Indonesia Tera.

Cobley, Paul dan Litza Jansz. 1997. Semiotics: For Beginners. Cambridge : Ikon Books.

Halim, Fachrizal A. 2002. Beragama dalam Belenggu Kapitalisme. Magelang : Indonesia Tera.
Muhadjir, Noeng dkk. 2000. Metodologi Penelitian Kualitatif. Yogyakarta : Rake Sarasin.

Piliang, Yasraf Amir. 2003. Hipersemiotika, Tafsir Cultural Studies atas Matinya Makna. Bandung : Jalasutra.

Saptari, Ratna dan Brigitte Holzner. 1997. Perempuan Kerja dan Perubahan Sosial, Sebuah Pengantar Studi Perempuan. Jakarta : Kalyanamitra.

Tomagola, Tamrin Amal. 1998. Citra Wanita dalam Iklan, dalam Majalah Wanita Indonesia; Suatu Tinjauan Sosiologis Media. Dalam Idi Subandy Ibrahim dan Suranto Hanif (ed)., Wanita dan Media : Konstruksi Ideologi Gender dalam Ruang Publik Orde Baru. Bandung.: Rosda.

Williamson, Judith. 2007. Decoding Advertisement, Membedah Ideologi dan Makna dalam Periklanan. Bandung : Jalasutra.

\section{Sumber lainnya :}

\section{Surat Kabar:}

Yasraf Amir Piliang. 2009. Narsisisme Politik. Dimuat dalam Kompas, Sabtu 17 Januari 2009

\section{Jurnal:}

Yasraf Amir Piliang. 1995. Wawasan Semiotik dan Bahasa Estetik Post Modernisme, Jurnal Seni Rupa volume I/95. H.33

\section{Internet:}

http://en.wikipedia.org

http://id.wikipedia.org

http://www.marxists.org 